Article

\title{
Investment Leverage for Adaptive Reuse of Cultural Heritage
}

\author{
Tracy Pickerill
}

check for updates

Citation: Pickerill, T. Investment Leverage for Adaptive Reuse of Cultural Heritage. Sustainability 2021, 13, 5052. https://doi.org/10.3390/ su13095052

Academic Editor: Pierfrancesco De Paola

Received: 16 February 2021

Accepted: 28 April 2021

Published: 30 April 2021

Publisher's Note: MDPI stays neutral with regard to jurisdictional claims in published maps and institutional affiliations.

Copyright: (C) 2021 by the author. Licensee MDPI, Basel, Switzerland. This article is an open access article distributed under the terms and conditions of the Creative Commons Attribution (CC BY) license (https:// creativecommons.org/licenses/by/ $4.0 /)$.
School of Surveying \& Construction Management, TU Dublin, Bolton Street, D01 K822 Dublin, Ireland; tracy.pickerill@TUDublin.ie

Abstract: This article tracks the design of a panoptic toolkit of complementary financial (grant and endowment, tax, debt and equity) and non-financial (regulation, real estate, risk mitigation and performance, capacity building, impact metric and digital network) instruments, designed to leverage capital investment and engender collaborative partnerships, to encourage investment capital to flow to cultural heritage adaptive reuse activities. Cultural heritage activities encompass adaptive reuse and energy retrofit of built heritage structures, protecting natural eco-systems and enabling local community enterprise activities. These activities embody circular economy dimensions, that stimulate social, cultural, environmental and economic regeneration, within the global value chain. Many cultural heritage investments entail long-term time horizons, requiring patient investment strategies. Consideration of the financial landscape, with regard to capital investment leverage is as much about understanding the motivations of participants to engage in the capital markets, as about innovations in financial instruments to safeguard cultural heritage values. Individual financial instruments, within the toolkit, such as debt and equity tools, are not new and some have a long association within traditional capital markets. What is new, is a framework for the engagement of blended complementary instruments, pooled within diverse multidisciplinary collaborative social enterprise fund structures, to achieve intentional and measurable impact investment returns. Risk adjusted investment return metrics include the analysis of socio-cultural and environmental impact returns in unison with market based financial returns, including below market returns in some instances. A case study of a revolving social impact fund is provided to give a practical example of combined complementary hybrid financial instruments within a collaborative funding structure. The ultimate choice and design of blended and pooled hybrid tool combinations and hybrid fund structures will change from building to building, and community to community, but must always prioritize the need to protect people and ecosystems in parallel with saving vulnerable cultural heritage resources. The selection of tailored hybrid financial instruments, to enhance circular economy transitionary ambitions, must remain flexible within a long-term collaborative investment strategy. The key change in mindset, central to cultural heritage financial toolkit development, is the enablement of capital leverage investment strategies that prioritize people and the ecosystem over pure profit motivation.

Keywords: cultural heritage; adaptive reuse; investment leverage; financial instruments; circular finance; social enterprise; market risk; market return; impact return; Taxonomy

\section{Introduction}

The investment needs of urban, peri urban and rural areas to achieve sustainable growth varies depending on the size of urban conurbations and rural clusters, demographic trends, geographic location, political and economic stability and the quality of existing assets, including cultural heritage assets. Altered financial markets, coupled with dysfunctional non-prime real estate markets, stemming from political and economic disruption over the last decade and more recently the economic turbulence caused by the pandemic has exacerbated this situation and negatively impacted on the financial viability of many cultural heritage activities, including:

- Adaptive reuse and energy retrofit of cultural built heritage structures; 
- Protection and management of natural eco-systems;

- Local community social enterprise activities.

Government revenues are still the primary source of funding for urban and rural development in many regions across Europe. Local governments face multiple financial constraints including insufficient and unpredictable monetary support from central government, weak fiscal structures, poor revenue generation from civic assets and legal constraints. A global survey of 100 cities found that $55 \%$ of municipalities cited lack of public funding as a barrier to sustainable urban growth [1]. Many countries have now been forced to reallocate their financial resources to deal with the multi-dimensional impacts of the pandemic to protect economic, environmental and social conditions of vulnerable populations. The Europe Court of Auditors encourage the use of private funds to safeguard Europe's cultural heritage and recommend that the European Commission strengthen the financial sustainability of cultural sites funded by the European Regional Development Fund [2].

Cultural heritage investment and social enterprise activities, by their nature, involve long term (sometimes perpetual) investment horizons which require integration of sustainable and circular investment principles. The design of circular financial instruments has the potential to make a contribution towards the transition to systemic sustainability and circular economy practices within the built and natural environment. Creating value, within the cultural heritage financial landscape, is as much about understanding existing and opportunistic relationships between collaborative capital leverage enablers, as about blending complementary financial instruments. To contribute to the quest for circular investment strategies, this article tracks the development of a flexible toolkit of complementary financial and non-financial instruments, designed to leverage capital investment and encourage collaborative social enterprise partnerships for the adaptive reuse of cultural heritage.

\subsection{European Investment Stimulus}

European Investment Bank (EIB) makes the case for a 'New Heritage Deal for Europe' to encourage heritage-led transformation of Europe's society, economy and environment, with the process powered by civil society and supported by local, regional, national and European organizations and institutions [3]. This case is supported by the President of the European Commission stating

"If we manage to use our ever changing and vibrant European culture and heritage as a powerful catalyst for change, and as a vital component of a new European Bauhaus, the return on investment will be substantial." [4]

The Cultural Deal for Europe acknowledges the role cultural, creative, heritage and philanthropic sectors can play in healing the cultural ecosystem post pandemic [5]. The European Union identifies the need for innovative action to enhance the capacity of cities to address global urban challenges, within holistic perspective, by creating climate neutral and smart, citizen-centric, sustainable, inclusive, resilient and safe systems [6]. The European Parliament recognize the value of cultural heritage, education and skills, digital cultural heritage, economic potential, sustainability and finally the need for a strategic approach to cultural heritage [7]. Europe Nostra highlights the 'multiple value of shared cultural heritage and an integrated EU strategy towards cultural heritage, with stronger synergies between stakeholders, policies and funding programmes, to fully unlock social, economic and environmental benefits' [8]. To address the exclusion of the cultural heritage agenda within the European Green Deal, a recent expert consultation, coordinated by ICOMOS and Europa Nostra, explores the opportunities and capacity for cultural heritage to contribute towards the implementation of the European Green Deal [9].

The Circular Economy (CE) Action Plan for Europe highlights the development of a strategy for a sustainable built environment and the potential of the 'Renovation Wave' initiative, announced by the European Green Deal, to align with circular economy principles [10]. Within the CE Action Plan, crosscutting actions refer to the integration of 
circular economy goals within the development of EU Taxonomy Regulations, by providing a circular economy finance support platform, and also developing ecolabel criteria for financial products [10].

\subsection{The Cultural Built Heritage Investment Enigma}

Tangible built heritage assets (bricks and mortar) provide a distinctive cultural context for urban and rural landscapes. Dysfunctional non-prime real estate markets and heightened risk of debt distress, stemming from political and economic turbulence over the last decade, have negatively impacted on the financial viability of many cultural heritage activities. Market failure, can potentially result in inappropriate adaptation or demolition of built heritage cultural assets unless gap finance can be sourced from limited public finances or sympathetic private benefactors, leaving the fate of many cultural assets to profit driven real estate markets and political whim.

The fact that built heritage resources form a cohesive layer within the real estate investment and development marketplace, creates an opportunity for developing circular placemaking investment strategies that contribute to cultural valorization and human wellbeing, whilst also saving finite resources for current and future generations. Place-led investment leverage strategies, within a circular economy framework, characterized by an accumulation of physical, economic and social problems, can create a platform for collaborative public, private and community engagement to foster resilience. Built heritage is also a vector for climate action transition and has the capacity to make a very real contribution to the European Green Deal with the initiation of strategic innovative green finance mechanisms [1].

The application of circular economy to the construction industry requires an understanding of the broader context in which development takes place, including the whole building life cycle assessment and the construction value chain [11]. Understanding the motivations and ability of stakeholders within the value chain to create value, as opposed to waste, is a necessary prerequisite to encouraging transitionary innovations in procurement and stakeholder collaboration within the design of circular financial instruments [12,13].

Stakeholders in the 'use' phase, (and by association, the 'reuse' phase in the case of adaptive reuse) including owners, occupiers, investors, developers, facility managers and financiers are fundamental to driving a circular built environment by deciding to adopt alternative strategies, structures and operation models to capture broader global socio-cultural, environmental and financial benefits [11].

The launch of the 'Renovation Wave Strategy', by the European Commission, will mobilize regenerative investment in the built environment. Renovation Wave funding, enabled within NextGenerationEU 'Renovate' and 'Power Up' funding initiatives of the European 'Recovery and Resilience Facility', incorporates combined grants and loans [14,15].This strategy will entail breaking down barriers within the renovation chain, via local community approaches, to integrate renewable and digital solutions to improve energy performance, achieve zero energy districts, reduce energy poverty and stimulate investment in local supply chains [14,15]. Although not directly created for built heritage purposes, Renovation Wave targeted funding strategies will potentially leverage investment in cultural heritage activities within the generic built environment industry.

\section{Methodology}

\subsection{Research Query}

To contribute to the quest for investment strategies to encourage regenerative investment leverage for cultural heritage adaptive reuse, this article poses the research query:

Can circular financial instruments be designed and tailored to protect people and ecosystems in parallel with adaptive reuse of vulnerable cultural heritage resources?

This query forms part of the Horizon 2020 research project CLIC: Circular models Leveraging Investments in Cultural heritage adaptive reuse [16]. This article tracks the development of a blueprint for a flexible toolkit of financial instruments to leverage investment 
in cultural heritage activities taking account of guiding principles in cultural landscape management policy and circular economy perspective, in addition to diverse stakeholder motivations to engage.

Based on literature review, the CLIC toolkit incorporates identified umbrella categories of both financial and non-financial instruments, together with identified socio-cultural, environmental and economic impact investment leverage enablers, that have the potential to generate mutually beneficial collaborative investment synergies in the adaptive reuse of cultural heritage.

Detailed analysis of the toolkit elements, with allied case study examples, forms part of the CLIC Project research Deliverable 4.1 Overview of Hybrid Financial Instruments and Investment Leverage Enablers for Cultural Heritage Adaptive Reuse [16].

\subsection{Defining the Terms of the Enquiry}

\subsubsection{Cultural Heritage}

Kobalt provides a broad definition of 'cultural heritage' as "works of art, architecture, cultural achievements and understanding the environment that has passed from earlier generations" [17]. The intangible dimension of cultural heritage is difficult to define [18] and 'nomadic' due to ever changing values and social norms through time and across groups [19].

\subsubsection{Cultural Capital}

The term 'cultural capital' remains central to understanding cultural heritage value creation in the financial landscape. Cultural Capital is the "capital value that can be attributed to a building, a collection of buildings, a monument or more generally a place, which is additional to the value of the land and buildings purely as physical entities or structures, and which embodies the community's valuation of the asset in terms of its social, historical or cultural dimension" [20]. Throsby reasons that pure economic value is not capable of expressing the full range and complexity of cultural worth where multidimensional attributes, such as architectural style, aesthetic quality, spiritual meaning, social function, symbolic significance, historical importance and uniqueness, cannot be quantified into financial terms necessary for clear decision making [21].

\subsubsection{Adaptive Reuse}

The term 'adaptive reuse' relating to cultural heritage activities is defined by Foster, as "the retrofit, rehabilitation and redevelopment of one or more buildings that reflects the changing needs of communities" [22]. Adaptive reuse provides a strategy aimed at preserving social, cultural, environmental and economic values, while at the same time adapting obsolete built heritage for new, extended and/or shared uses.

\subsubsection{Circular Economy}

Ellen MacArthur Foundation (EMF) define Circular Economy (CE) as a systemic approach to economic development designed to benefit businesses, society and the environment. In contrast to the 'take-make-waste' linear model, a circular economy is regenerative by design and aims to gradually decouple growth from the consumption of finite resources [23]. As a sustainability concept, circular economy promotes human wellbeing within the biophysical limits of the planet earth. The useful life of materials is extended through transformation into new products, design for longevity, waste minimalization, reuse and rethinking consumption to include sharing and services provision instead of individual ownership [22].

The concept of a regenerative, generative and symbiotic 'Triple Circular' adaptive reuse strategy developed by Fusco Girard provides a valuable guiding principle for decision makers to inform the choice and design of holistic regenerative funding mechanisms that align with the ultimate goal of achieving value creation where societal, environmental and financial benefits are in equilibrium [24]. 


\subsection{Toolkit Design}

Three bodies of knowledge are critical to the development of efficient and effective financial and non-financial instruments to leverage investment funds, mitigate risk and build human and institutional capacity for the adaptive reuse of cultural heritage, while maintaining a symbiotic human and ecological centric vision:

(i) Tool Knowledge relating to the operational characteristics of different financial instruments;

(ii) Design Knowledge (including blending capacity) to facilitate matching complementary instruments to the needs of target recipients in order to relieve the burden of investment funding gaps, remove investment barriers and avoid displacement;

(iii) Stakeholder Knowledge including collaborative partnership motivations and capacity to engage [25].

The ultimate choice and design of hybrid financial instruments by stakeholders must remain mindful of the physical, humanistic and ecological synergies that exist within complex cultural landscapes. It is not just a technical decision, based on the most efficient way to solve particular public or private funding gaps. Decisions about funding strategies are influenced by political and economic context, pre-existing institutional structures, the inclusion of diverse communities and ideological pre-dispositions regarding socio-cultural and environmental goals. Fusco Girard and Gravagnuolo [26] highlight the capacity of cultural heritage circular economy strategies to create synergies to tackle combined human poverty and ecological climate challenges within a symbiotic vision of the landscape.

\section{The Role of Market Spheres for Investment Leverage}

While the role of public action to leverage private investment should never be underestimated, it is important to highlight the significant contribution of social venture philanthropic strategies (patient social enterprise investors) to achieve social impact returns for the common good. Local communities, in collaboration with non-profit philanthropic foundations and trusts maintain a significant role in promoting, lobbying and providing capacity building and financial support for place-led cultural heritage activities. Potential financial intermediaries and collaborative beneficiaries include:

- Supra national entities, such as, the European Commission (EC), European Structural and Investment Fund (ESIF), European Social Fund (ESF), European Central Bank (ECB), Council of Europe Development Bank (CEB) and Climate Bank (CB);

- Public sector state authorities, state agencies and quasi agencies;

- Private sector non-profit foundations and trusts (philanthropy);

- Private sector for-profit investment, development, financial and enterprise entities, including certified B-Corporations (purpose with profit);

- Public-Private Partnership arrangements, more recently Public, Private, People Partnership arrangements, including local community initiatives.

Innovative hybrid collaborative fund structures, developed at European level, create a strong framework to inform the design of private sector funding mechanisms. The true added value of hybrid European financial instruments is reflected in benefits such as recycled investment funds, network connections, knowledge sharing, capacity building, risk mitigation, social inclusion, investor confidence, lower energy consumption, training and job creation. For example, the Just Transition Mechanism (within NextGenerationEU) consists of three funding pillars as follows. The Just Transition Fund (1st pillar 2021-2024) will provide matching grant aid of Eur 40 bn to EU member states, with expected investment leverage of circa Eur 89-107 bn. The dedicated Just Transition scheme under InvestEU (2nd pillar) will crowd-in private investment estimated at circa Eur 30 bn. The European Investment Bank (EIB) public sector loan facility (3rd pillar 2021-2027) will administer Eur 10 bn in loans, backed by a Eur 1.5 bn EU budget, to leverage public investment (with an estimated mobilisation of circa Eur 30 bn of public investment supporting just transition objectives). The InvestEU guarantee scheme provides a risk mitigation instrument 
designed to leverage private finance in support of circular economy transition, including sustainable infrastructure, research innovation and digitization; SMEs and social enterprise investment including microfinance, skills and integration of vulnerable communities. A technical and advisory platform provides capacity building support for potential public and private investors and financial intermediaries [27].

\subsection{Investment Motivations of Market Spheres}

At the State level, traditional governance models include collaborative partnerships between government, for-profit and non-profit entities, including:

- 1 st Market Sphere: Direct and indirect public action for the common good (funded by tax collection and borrowing);

- 2nd Market Sphere: Profit motivated business entities (tax liability);

- 3rd Market Sphere: Mission motivated non-profit philanthropic entities (tax exempt) such as cultural foundations and charitable trusts;

- Hybrid traditional Public-Private Partnership models, including 1st, 2nd and 3rd Spheres.

Within the 1st market sphere, direct demand-side government policies involve financial instruments such as bond issues, grant-aid and direct government loans where the state directly transfers money to another stakeholder to finance (or part finance) cultural activities. The cost of implementing regulatory policy also involves a direct cost to the state. Indirect supply-side government policies involve financial instruments such as tax incentives, loan guarantees and capacity building (such as knowledge sharing and technical support) where no direct transfer of money and no state expenditure is recorded.

In recent years, innovative financial instruments have started to emerge in the marketplace, demonstrating that parallel profit motive and public benefit common good can work together within flexible governance structures. This hybrid structure, incorporating combined for-profit and non-profit elements, aims to both leverage investment capital and build human and institutional capacity for socio-cultural and environmental problem solving [28] adding a 4th economic market sphere:

- $\quad 4$ th Market Sphere: Profit and intentional measured impact motivated socio-cultural and environmental entities with complex legal and tax structures due to hybrid forprofit, reduced-profit and non-profit structures.

Achleitner and SpeissKnafl identify emerging leverage enablers (4th market sphere within this article) in social capital markets as value banks, venture philanthropy funds, social Investment funds and advisors, social stock exchanges and crowd funding platforms [29]. Salamon adds capital aggregators, philanthropic banks, corporate originated philanthropic foundations (mutual funds), enterprise brokers and climate exchanges to this evolving list [30]. Gianoncelli and Boiardi refer to 'social enterprise' investment entities, defined as an "organization that focuses on achieving social impact, applying market-based solutions to address public sector and market failure in innovative ways" [28].

\subsection{Public-Private Partnerships Structures}

Public-Private Partnership (PPP) mechanisms, involving cross-sector collaboration, have become an increasingly important tool of government action to deliver social infrastructure including urban and rural regeneration schemes. International experience with PPP approaches has been mixed regarding the governance of PPP procurement including issues in relation to ex-ante and ex-post evaluation of Value For Money (VFM) and risk transfer [31,32]. The European PPP Expertise Centre (EPEC) suggests that the successful use of the PPP mechanism depends on conducive legal regulatory and institutional framework and processes [33,34].

EPEC makes specific reference to funding and financing PPP projects and makes a distinction between funding and financing sources [34]. Funding sources include taxpayers and end user toll payments, while financing sources are used to bridge the gap between project inception and completion and include debt and equity financial instruments. The 
point being that financial instruments do not address the funding issue, as ultimately the loan and/or equity investment must be repaid, regardless of whether the PPP cost is recorded on or off the government balance sheet. International practice advocates the establishment of specialized PPP governance agencies as part of the development of institutional frameworks to support PPP procurement [35-37]. To establish Value for Money (VFM), O'Shea, Palcic and Reeves advise that projected PPP costs should be compared with conventional procurement, via a Public Sector Benchmark (PSB), completed prior to the receipt of tenders [38].

\section{Creating Circular Hybrid Financial Instruments for the Common Good}

\subsection{Financial Instruments}

Financial instruments (FIs) entail the provision of finance to an organization, enterprise or individual with the expectation of both social and financial returns [39]. FIs leverage private investment by channelling funds to final recipients via multi-layer structures involving public and/or private co-financing modalities of beneficiaries such as member state authorities, investors, intermediaries and Fund of Funds (FoF). Specific advantages of creating FIs include:

- Leverage capacity to attract combined public and private resources;

- Revolving capacity to generate recycled flows of money via loan repayments (debt) or the realisation of investments (equity);

- Circular revenue generation and regeneration;

- Access to private sector financial tools and expertise to support public policy goals within collaborative public-private fund structures [40].

The most common source of start-up capital for revolving funds is endowments from government agencies, cultural foundations or corporations. Lending institutions can provide funding in the form of debt finance secured by collateral assets or personal guarantees. As funds gradually become depleted, fund-raising is an ongoing activity of most revolving funds.

FIs provide financial discipline, for resource-efficient and sustainable revenue generating flows of capital, to maximize private investment and relieve the financial burden of government authorities by providing 'financial citizenship' to disadvantaged people [41,42]. Financial instruments may take the form of grants, equity or quasi-equity investments, debt (loans) or guarantees, or other risk-sharing instruments [40].

\subsection{Hybrid Financial Instruments and Tailored Financing}

European Investment Bank (EIB) also categorise financial instruments as loans (debt), guarantees, equity and quasi equity, however recognise additional mixed forms of financial instruments, termed 'Blended Finance' or 'Hybrid Capital' blending combinations of grant, equity and debt capital [41].

The World Economic Forum (WEF) defines 'Blended Finance' as the strategic use of development finance and philanthropic funds to mobilize private capital flows to emerging and frontier markets. Blended finance deliberately channels private investment to sectors of high-development impact, while at the same time delivering risk-adjusted returns. Blended finance has three key characteristics:

- Leverage: Use of development finance and philanthropic funds to attract private capital into deals;

- Impact Return: Investments that drive measured social, environmental and economic progress;

- Financial Return: Financial returns for private investors in line with market expectations, based on real and perceived risks [40].

Organisation for Economic Co-operation and Development (OECD) Blended Finance Principles [43] state that blended finance should be anchored to a development rationale, designed to increase commercial finance, tailored to a local context, designed to ensure 
efficient partnering and monitored for transparency and results. Pooled financial instruments entail collaborative partnerships to solve the parallel needs of local authorities and local communities by raising combined funding on the capital markets via various blended financial instruments. Pooled finance can take different forms depending on the country context and stakeholder requirements. Apart from knowledge sharing, the pooling of assets to raise finance allows for mitigation and diversification of risk for investors, creates economies of scale and enables less experienced partners to improve their credit rating.

Gianoncelli and Boiardi make a distinction between the terms 'Tailored Financing' and 'Hybrid Financial Instruments' in the context of venture philanthropy or social enterprise investment organizations. Tailored Financing is the process whereby investors choose from a range of available financial instruments (grant, debt, equity and hybrid financial instruments) where the choice is dependent on the risk, return and impact profile of the investor. Hybrid Financial Instruments (HFI) are monetary contracts that combine features of traditional financial instruments (grant, debt and equity instruments) to achieve the best possible alignment of risk and impact/financial return for particular investments [28].

\subsection{Sustainable and Circular Financial Reporting}

European Court of Auditors (ECA) defines 'sustainability reporting' as the practice of measuring, disclosing and being accountable to internal and external stakeholders for organizational performance towards the goal of sustainable development [44]. Sustainable investment strategies, including impact investment, ESG compliance and climate resilience building processes, effect the pricing of financial assets and the long-term risk and return opportunities of investments. Citizens are demanding responsible approaches to investment from governments, corporate entities and investors, as the primary providers of capital. This is leading to the reallocation of capital in the financial markets towards investment opportunities that can demonstrate transparent Environmental, Social and Governance (ESG) compliance [45]. Investment benchmarking is complicated by the fact that independent and unregulated rating agencies evaluate ESG analytics to inform investment markets. Kempeneer Peeters Compernolle identify a lack of a universal conceptualization of ESG and a divergence of ESG measurement practices among rating agencies, practitioners and academics [46]. Comparability issues between different rating agency metrics, increases the risk of capital misallocation, greenwashing and product mis-selling [47].

In line with the Action Plan on Financing Sustainable Growth in Europe [48] the Taxonomy Regulation [49], creates a legal basis for the EU Taxonomy and provides a framework to facilitate the development of an EU wide classification system for environmentally sustainable economic activities, including legal obligations for all financial market participants. The Taxonomy sets performance thresholds (technical screening criteria) for six environmental objectives, requiring economic activities to (i) Substantially Contribute to at least 1 objective; (ii) Do No Significant Harm (DNSH) to the other 5; and (iii) comply with minimum safeguards. The objectives include Climate change mitigation, Climate change adaptation, Sustainable protection of water and marine resources, Transition to Circular Economy, Pollution prevention and control, Protection and restoration of biodiversity and ecosystems [50].

The EU Taxonomy is an implementation tool for policy makers, industry and investors to enable capital markets to classify and respond to investment opportunities that contribute to green transition policy objectives. It is also a guidance tool to encourage investors to allocate capital or influence company activities that make a contribution to climate goals and related Sustainable Development Goals (SDGs). The more recent EU Taxonomy Principles propose five principles for recovery and resilience within EU financial recovery mechanisms [51]. The Principles identify the need to build social, economic and ecological ecosystem resilience in preparation for future climate related disruption. In parallel with protecting vulnerable communities, the Principles highlight the importance of creating robust collaborative financial investment frameworks to attract private investment 
to support and reinforce both member state and collaborative transnational investment towards reaching zero emission targets.

\subsection{Circular Business Models}

While the development of Circular Business Models (CBMs) lies outside the remit of this article, it is important to state that Financial Instruments (FIs), for the adaptive reuse of cultural heritage, can be optimally designed within CBMs. Essentially, FIs can address the needs of final recipients and also take account of the motivations, capabilities and structures of investors and financial intermediaries (beneficiaries) within complex social investment financial ecosystems. Sustainable and/or circular transitions in business model innovation is an evolving process, which needs to remain flexible as new innovations emerge within complex diverse multi stakeholder process networks.

\section{Understanding Risk-adjusted Market and Impact Return Metrics}

European Investment Bank (EIB) highlight the drive to create enabling financial environments for social impact investment, addressing societal challenges, with the explicit expectation of achieving a measurable social, as well as financial return [52]. Risk adjusted market return is the financial return for private investors in line with market expectations, based on real and perceived risk. Investments that drive combined social, environmental and economic (financial) progress are termed 'triple bottom line' investments [40]. The use of financial instruments designed to achieve socio-cultural and environmental impacts, in addition to a risk adjusted financial return, carry an additional impact liability, as failure of a financial instrument could negatively impact vulnerable people or communities. This creates a two-tiered risk spectrum of:

- $\quad$ Risk adjusted Market Return on capital or Below Market Return of capital;

- $\quad$ Risk adjusted Impact Return;

Individual investors within collaborative hybrid fund structures have different risk and return motivations to engage, dependent on the political, economic and geographical context of their use.

\subsection{Market Return Metrics}

Internal Rate of Return (IRR) analysis provides a tool to benchmark financial investment across the spectrum of asset classes (equity, debt and real assets such as real estate). It is defined as the annual rate of return (annual growth expectation) that generates a Net Present Value (NPV) of zero for a stream of expected (or actual) cashflows [53]. The IRR metric is limited in its analytic insight, as it does not explicitly measure the size and length of the investment, timing and stability of expected cash flows, investment management capacity or liquidity/exit risk. In the specific case of investment decisions relating to adaptation or retrofit of built heritage tangible assets, IRR does not distinguish between location, quality of adaptation, cost overrun risk, tenant credit risk, leasing risk, or exit liquidity [53]. Another financial benchmark tool is the Opportunity Cost of Capital (OCC) relating to the foregone benefit when choosing one investment strategy over another. Investors can estimate OCC deployment by taking several investment facets into account alongside risk and return, such as liquidity, resource capacity, impact performance expectations and impact risk tolerance, thus providing a multifaceted approach to decision making [54].

\subsection{Impact Return Metrics}

The impact measurement process may entail a combination of both internal institutional analysis and external independent analysis in order to measure and benchmark both positive and negative impact within the investment leverage process. The key elements of Impact Measurement and Management (IMM) are intentionality, impact measurement and financial return. Individual and institutional investors are increasingly demanding rigorous IMM practices to align with global sustainable development agendas. Global Impact Investing Network (GIIN) acknowledge that although IMM practices have matured in the 
last decade (IRIS+ Core Metric sets and Impact Management Projects for Financial Markets) opportunities for further refinement remain $[54,55]$. The European Venture Philanthropy Association (EPVA) provide a step-by-step toolkit of strategies and best practice to assist investors for impact [56]. GIIN analysis on 'The State of Impact Measurement and Management Practice' highlights interpretation, comparison and validation of impact results to negate 'impact washing', as the most significant challenge facing impact investors [55].

Asset allocation specific to cultural heritage activities cannot be clearly determined within the sector analysis categories used by GIIN. The GIIN sectoral investment category of 'other' relating to 'real estate, tourism, community development, retail and agnostic investors' could potentially relate to adaptive reuse of cultural heritage activities, but may overlap with other GIIN analysis categories including, inter alia, infrastructure, energy, housing, microfinance, forestry and arts/culture investments. Despite this lack of clarity, interesting observations are apparent regarding the relationship between asset class (debt, equity, quasi equity, real assets and cash deposits) and risk adjusted market returns in the 2020 GIIN Annual Impact Survey:

- Sources of capital for impact investing asset managers originated from pension funds, companies, commercial investors, financial institutions, development financial institutions, High Net Worth Individuals, (HNWIs), foundations, Fund of Funds (FoF), sovereign wealth funds, endowments and 'faith-based' spiritual institutions;

- Private equity focused investors are more lightly to seek risk adjusted market rate returns, while private debt focused investors are more likely to employ capital preservations investment strategies;

- Returns from private equity investments, as an asset class, are more volatile, with greater return ranges than private debt and real assets [57].

Social Enterprise Investment for Impact versus Investment with Impact

Gianoncelli and Boiardi make a distinction between 'investing for impact' and 'investing with impact', along a spectrum of impact investment strategies including:

- Investors for impact (Impact 1st) prioritize the achievement of intentional longterm social impact (patient investors) with or without financial return, ranging from financial loss to capital preservation below market return.

- Investors with impact (Finance 1st) prioritize the achievement of positive financial returns, with the achievement of social impact as a secondary goal [58];

Within these two extremes, a range of financial return, risk mitigation and environmental, social and governance (ESG) impact generation strategies exist to support social enterprise at different stages of the development (ex-ante, seed, start-up, scale-up and ex-post evaluation) within different levels of market sector maturity [58]. Financial instruments can be designed and tailored to the specific needs of each of the above stages of development in political and economic context.

\section{Arriving at an Integrated Panoptic Investment Leverage Toolkit for the Adaptive Reuse of Cultural Heritage}

Based on the above analysis of literature and policy guidance documents, the CLIC investment leverage toolkit incorporates 'umbrella' classifications, of both financial and non-financial instruments, designed to leverage capital investment and encourage collaborative social enterprise partnerships within financial markets, for the adaptive reuse of cultural heritage. Flexible financial and non-financial instruments can be:

(i) Blended with complementary instruments within tailored heritage-led, place-led or typology-led* initiatives;

(ii) Pooled within collaborative hybrid fund structures.

*'Typology-led' initiatives can relate to building type (such as Civic, Spiritual, Industrial, Residential, Commercial) or vintage architectural style (such as, inter alia, Ancient, 
Islamic, Classical, Byzantine, Romanesque, Gothic, Renaissance, Baroque, Rococo, Neoclassical, Art Nouveau, Art Deco, Bauhaus).

Table 1 shows the categorisation of identified social enterprise investment leverage enablers, along with financial and non-financial instruments, within an integrated panoptic toolkit, based on the theoretical perspectives discussed throughout this article.

Table 1. Mutually Beneficial Collaborative Investment Relationships.

\begin{tabular}{llll}
\hline & \multicolumn{1}{c}{ Investment Leverage Enablers } & & \multicolumn{1}{c}{ Financial and Non-financial Instruments } \\
\hline & & i. & Grant and Endowment Instruments \\
i. & Financial Intermediaries and Collaborative Funding & ii. & Tax Instruments \\
& Networks & iii. & Debt Instruments \\
ii. & Equity Risk Capital and Angel Investors & iv. & Equity Instruments \\
iii. $\quad$ Traditional and Hybrid Investment Philanthropic & v. & Risk Mitigation and Performance Instruments \\
& Foundations and Trusts & vi. & Impact Metric Instruments \\
iv. & Hybrid Philanthropic Donor Advised Funds & vii. & Heritage Regulation and Real Estate Instruments \\
v. $\quad$ Co-Giving and Co-Investment Platforms: Lottery Funds & viii. & Capacity Building Instruments \\
& and Crowd Funding & ix. & Digital Pathfinding Tools \\
& & & \\
\hline
\end{tabular}

Figure 1 provides a visualisation of the integrated panoptic CLIC Investment Leverage Toolkit highlighting the potential connectivity between 'Blended' complementary financial and non-financial instruments and 'Pooled' social enterprise investment leverage enablers.

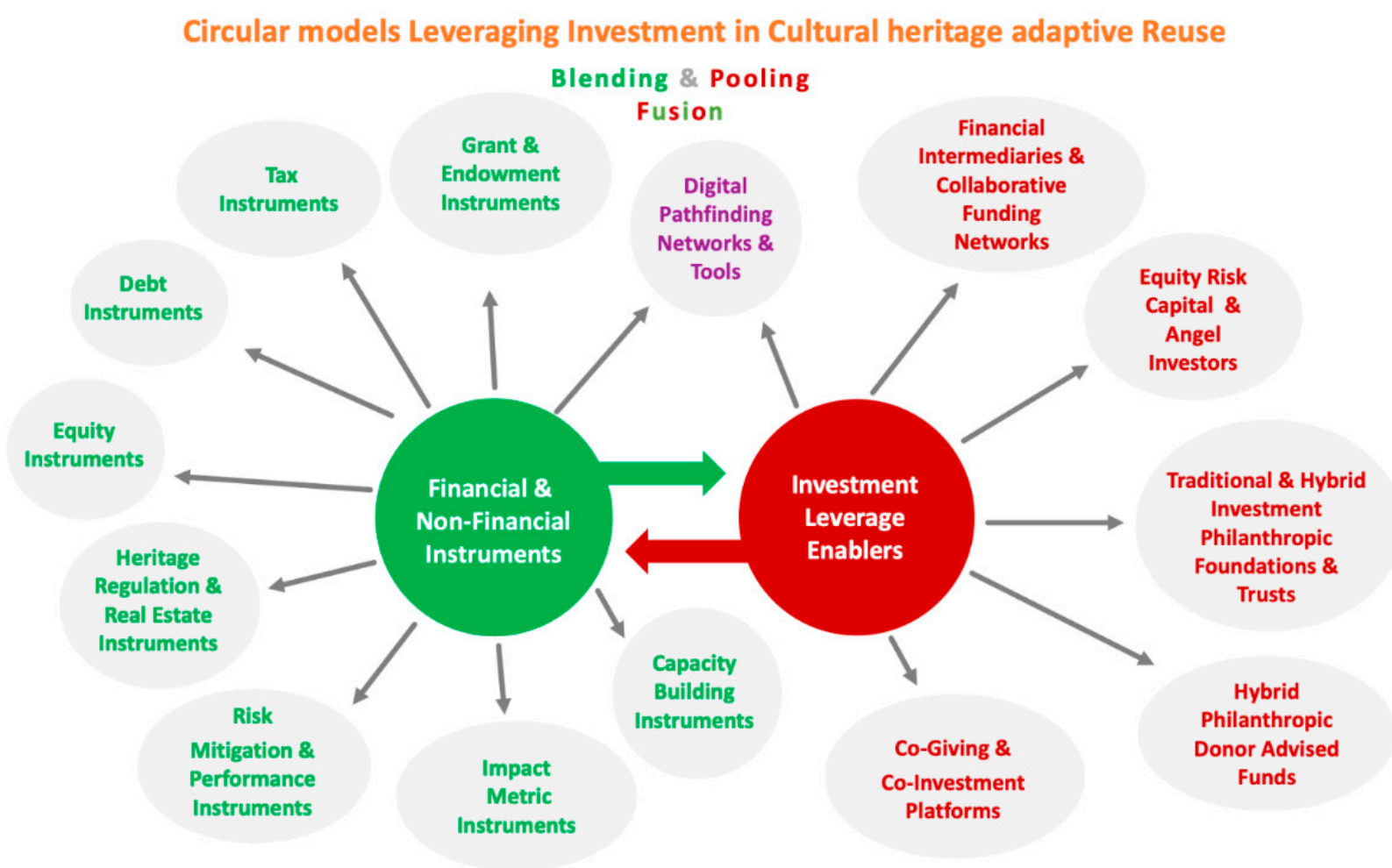

Figure 1. Integrated Panoptic Investment Leverage Toolkit.

Table 2 provides indicative tools within the identified umbrella categories of financial and non-financial instruments. The collation of this table of tools stems from research carried out for CLIC Deliverable 4.1 Overview of Hybrid Financial Instruments and Investment Leverage Enablers for Cultural Heritage Adaptive Reuse [16]. 
Table 2. Indicative tool examples within the identified CLIC Umbrella Categories.

\begin{tabular}{ll}
\hline \multicolumn{1}{c}{ Traditional Grant Instruments } & \multicolumn{1}{c}{ Grant and Endowment Instrument Enhancements } \\
\hline $\begin{array}{l}\text { Direct or Matching Philanthropic Grant aid including in-kind } \\
\text { volunteer contributions }\end{array}$ & $\begin{array}{l}\text { Philanthropic Grants and Endowments combined with } \\
\text { capacity building mentoring }\end{array}$ \\
Mortgage subsidy & Grants funded by Crowd Funding Ventures \\
& Prize and Competition Grant Awards \\
\hline
\end{tabular}

Traditional Tax Instruments

\section{Tax Instrument Enhancements}

Tax deduction, exemption or freeze:

Income/Corporation (Tax Credits) including

tax-deductible sponsorship

Property Tax

Value Added Tax (VAT)/Sales Tax

Transfer Tax (Stamp Duty)

Capital Gains Tax and Inheritance Tax

Land Value Capture (LVC) Instruments

Place-led, Heritage-led and Typology-led Tax

Credit Initiatives

Tax Increment Financing (TIF) Bond Instruments (form

of Land Value Capture)

Art-Bonus, Eco-Bonus, Super Bonus and Façade Bonus

Tax Credits

\section{Traditional Debt Instruments}

Debt Instrument Enhancements

Loans (Debt):

Commercial Bank Loans

Government loan ( $0 \%$ or low interest)
Loans (Debt):

Venture Capital Loan

Quasi Equity Venture Capital Loan

Micro Finance Investment Vehicles

Revolving Loan Funds

Green Finance Loans

Energy Efficiency Mortgage Label

Bonds (Debt):

Social Impact Government Bonds (tax exempt)

Social Impact Corporate Bonds (Long term Bond/Short term Note)

Bonds (Debt):

Government Bonds

Traditional Equity Instruments

Internal Rate of Return (IRR)

Opportunity Cost of Capital (OCC)

\section{Risk Mitigation Instruments}

Government Loan Guarantee (on Commercial Bank Loan)

Tax Increment Finance (TIF) Bond Instruments (form of Land Value Capture)

Human Capital Performance Bonds (Risk Performance Instrument)

Equity Risk Capital Instruments

Equity Share Instruments

Quasi Debt/Equity Share Instruments

ESG and Social/Environmental Impact Stock Exchange public listing

Private Placement Bond Market

\section{Risk Mitigation and Performance Instruments}

Corporate or Philanthropic Loan Guarantee

Risk Performance Instruments (Human Capital

Performance Bonds)

Micro Insurance (low-income recipient)

\section{Traditional Impact Metric Instruments}

Real Estate and Construction Market Metrics

GRESB: Global Real Estate Sustainability Benchmark (ESG Integration)

Wired Score Certification

LEED and BREEAM Certification

WELL Certification

RESET Air Certification

nZeb Certification (EPBD)

Net Zero Carbon Standard (World Green Building Council WGBC)

\section{Impact Metric Instrument}

Governance Metrics

ESG Compliance incorporating SDGs mapping

EU Taxonomy Compliance

B Corporation Certification

Financial Metrics

Internal Rate of Return (IRR)

Opportunity Cost of Capital (OCC)

Intentional Impact Metrics

IRIS Catalogue of Metrics

IRIS+ Core Metric Sets

Impact Management Projects (IMP) Financial Markets 
Table 2. Cont.

Heritage Regulation and Real Estate (RE) Instruments
Heritage Regulation and Real Estate (RE)

Instrument Enhancements

\begin{tabular}{|c|c|}
\hline $\begin{array}{l}\text { Direct and Indirect Investment Structures: } \\
\text { Public-Private Partnership (PPP) } \\
\text { Quasi Development Agencies } \\
\text { Master Planning } \\
\text { Strategic Development Zones }\end{array}$ & $\begin{array}{l}\text { Direct Investment Structures: } \\
\text { Public-Private Partnership (PPP) } \\
\text { Public-Private People Partnerships } \\
\text { Joint Ventures Schemes } \\
\text { Public Asset Corporations (publicly owned and } \\
\text { privately managed) } \\
\text { Indirect Investment Structures: } \\
\text { Real Estate Investment Trusts (listed or unlisted) } \\
\text { Real Estate Investment Companies and Funds (listed or } \\
\text { unlisted) } \\
\text { B Corporation (public benefit for-profit) } \\
\text { Revolving Funds }\end{array}$ \\
\hline $\begin{array}{l}\text { Real Estate Regulatory Instruments: } \\
\text { Transfer Development Rights (TDR) } \\
\text { Planning Bonus } \\
\text { Easement Donations }\end{array}$ & $\begin{array}{l}\text { Real Estate Regulatory Instruments: } \\
\text { Land Value Capture (LVC) } \\
\text { Betterment Levies and Taxes } \\
\text { Developer Contributions } \\
\text { Leveraging public land assets. } \\
\text { Renovation Lease } \\
\text { Social Value Lease } \\
\text { Energy Efficiency Mortgage Label }\end{array}$ \\
\hline $\begin{array}{l}\text { Direct Service Provision and Advisory Instruments } \\
\text { (Cultural Heritage) }\end{array}$ & $\begin{array}{l}\text { Capacity Building Instruments (Networking, } \\
\text { Mobilisation and Mentoring) }\end{array}$ \\
\hline $\begin{array}{l}\text { Technical or Advisory Service by Supra-national or National } \\
\text { Government Agency }\end{array}$ & $\begin{array}{l}\text { Networking and Mobilising Collaboration Technical } \\
\text { business mentoring (Social Enterprise Angel Investors) } \\
\text { Education and Skills Training } \\
\text { Technical Repair and Maintenance Support }\end{array}$ \\
\hline
\end{tabular}

Digital Pathfinding Online Portals/Tools:

Cultural Heritage Portals

Environmental Portals

Philanthropic and Social Enterprise Impact Investment Portals

Stock Exchange Portals

Crowd Funding Portals

Lottery Funding Portals

Source: CLIC Deliverable 4.1 [16].

\section{Case Study: Calvert Impact Fund (USA)}

Calvert Impact Capital (CIC) Inc. is an impact 1st social enterprise financial intermediary with a mission to create a more equitable and sustainable world. The hybrid impact fund collaborates with both individual and institutional investors to raise patient investment capital, via:

- Community Investment Note (short-term bond);

- Co-lending syndication service.

'Calvert Giving Foundation' a donor advised mutual fund, launched in 2000, became a separate autonomous fund 'Impact Assets' in 2010 [59]).

\subsection{Calvert Community Investment Note}

The Community Investment Note is a bond instrument, launched in 1995, with endowment finance from the Ford, MacArthur and Mott Foundations. The Note raises funds from a diverse range of individual (min. USD 20) and institutional investors to finance a global portfolio of high impact community-based intermediaries and funds that onward finance mission driven social enterprise and community activities, excluded from traditional capital markets. Community investment Notes are sold directly on the Calvert 
Impact Capital online investment platform (calvertimpactcapital.org/invest), indirectly by brokers and online via MicroPlace. Since inception, the Note has raised USD 2 billion from circa 18,000 investors and serviced over 500 borrowers with 100\% investor repayment rate. Funds are used for loan capital (micro and bridging finance). Interest earned on the loans covers the interest obligation to investors and makes a contribution towards operating expenses of the foundation, with the remainder being raised from grants and donations. This taxable unrated medium-term Note allows investors to select a term of 1 to 15 years with rates from 0.5 to $3.5 \%$. The notes are unsecured without collateral backing [59].

\subsection{Calvert Co-lending Syndication Service}

In 2017, Calvert Impact Capital launched a syndication service for institutional colenders offering a diverse range of risk/return profiles and competitive financial returns. The syndication service acts as a go between to reduce friction between the demand and supply of capital. Since inception, the syndication service has collaborated with 44 lenders to leverage USD 300.08 million in funds [59].

\subsection{Catalytic and Revolving Investment Leverage and Capacity Building Support}

Capital leveraged from the Note programme and Syndication Service is channeled, via loans and equity investments, to other financial intermediaries and funds to enable them to expand equity into communities that cannot access traditional financial markets.

The strategy of channeling funds through additional financial intermediaries and funds is that Calvert beneficiary entities can potentially use Calvert impact capital funds to leverage and aggregate additional capital to onward lend to final recipients, such as affordable housing developments, community regeneration activities, SMEs and entrepreneurial community projects.

Calvert Impact Capital assists borrowers (beneficiaries and final recipients) to build capacity within their business models to sustain a track record of performance, repayment and positive returns. This capacity building element facilitates borrowers to attract further capital in the future through traditional financial markets. In 2019, Calvert Impact Capital distributed USD 108 million in loans to financial Intermediaries and funds (beneficiaries), which then onward dispersed USD 5.02 billion in loans to final recipients across the globe. In $2019,64 \%$ of the Calvert portfolio was invested in the US and 36\% internationally, across 107 countries [59].

\subsection{Calvert Intentional Impact Metrics}

Calvert Impact analysis relates to investment leverage for underinvested communities, addressing social inequality and economic deprivation. Strategic investment in climate change mitigation and adaptation is analyzed within the categories environmental sustainability, renewable energy and sustainable agriculture. All impact assessment categories within global communities are aligned with the Sustainable Development Goals (SDGs) [60]. Specifically, three layers of impact are analysed, utilising both internal and external (IRIS+ and Impact Management Projects-IMP5) data sources, through each investment lifecycle:

- Investor Impact: measuring benefits for individual and institutional investors and co-lenders;

- Portfolio Impact: measuring the value and sustainable growth opportunities that leveraged capital provided to borrowers;

- Community Impact: measuring inequality and climate change solutions achieved from capital invested in global communities [59].

Investor impact metrics reflect the outputs and outcomes on investors and co-lenders, based on an internal investor survey and metrics on Note sales. Portfolio impact metrics reflect borrower performance, based on internal and external analysis and borrower reporting. Community impact metrics reflect borrowers' outputs and outcomes on the environment and in the communities they serve, based on external analysis. Portfolio and community impact reporting utilizes industry aligned indicators and best practices 
including IRIS+ and the Impact Management Project [IMP] five dimensions of impact to collect relevant impact data and alleviate the reporting burden on borrowers. Due to the blending of financial instruments and collaborative pooling of funding initiatives for community-based projects, measured metrics relate to the full community impact, rather than the impact of individual funding enablers.

Calvert Impact Capital (CIC) support co-lending impact funds, within the Calvert portfolio, that provide financial and capacity building support for urban and rural regeneration, affordable housing, community development, education, sustainable agriculture, microfinance, renewable energy and environmental sustainability initiatives [61]. For example, Finance in Motion, a German based fund manager, co-lends funds with Calvert Impact Capital, to the SANAD fund for MSME, which provides finance to institutions in the Middle East and North America (MENA) for on-lending to micro, small and medium enterprises (MSME) and low-income households. Similarly, Blue Orchard is a global impact investment fund providing blended debt and equity microfinance to institutions in emerging and frontier markets [61].

\subsection{Viewing Calvert Hybrid Impact Fund Structure in the Context of the Panoptic CLIC Toolkit}

The panoptic investment leverage toolkit is designed to assist individual and institutional investors to plan an investment leverage strategy for cultural heritage adaptive reuse projects or social enterprise initiatives. While the Calvert Impact Capital (CIC) case study is an existing developed fund, it provides a retrospective look at a revolving social enterprise impact fund to show how the various elements of the panoptic toolkit relate to each other.

In this case, Calvert Impact Capital acts as the main financial intermediary, aggregating capital from individual citizens (via online and broker bond sales) and institutional investors (via co-lending). Aggregated capital is then channeled (via onward patient low interest loans and equity share instruments) to collaborative impact funding entities (such as equity venture capital funds and philanthropic foundations) who aggregate additional leverage using the Calvert funds. These expanded funds are then onward channeled to final recipients (community regeneration initiatives, entrepreneurs and SMEs) in the form of patient investments via loan guarantees (risk mitigation instrument) and low interest loans (revolving loan debt instrument) in parallel with technical and advisory support (capacity building instrument). Final recipients may potentially add to these funds using additional financial instruments, such as grants, donations and crowdfunding instruments. All investment streams are justified by the use of intentional impact measurement and management (IMM) metrics, in additional to financial returns. Financial returns are enabled by loan repayments to the Calvert Fund and co-investors in addition to dividend returns to the Note (bond) investors.

Figure 2 provides a visualization of the generative, regenerative and symbiotic nature of the Calvert Impact Capital circular capital leverage process within the private capital market. 
Calvert Impact Capital Fund Structure

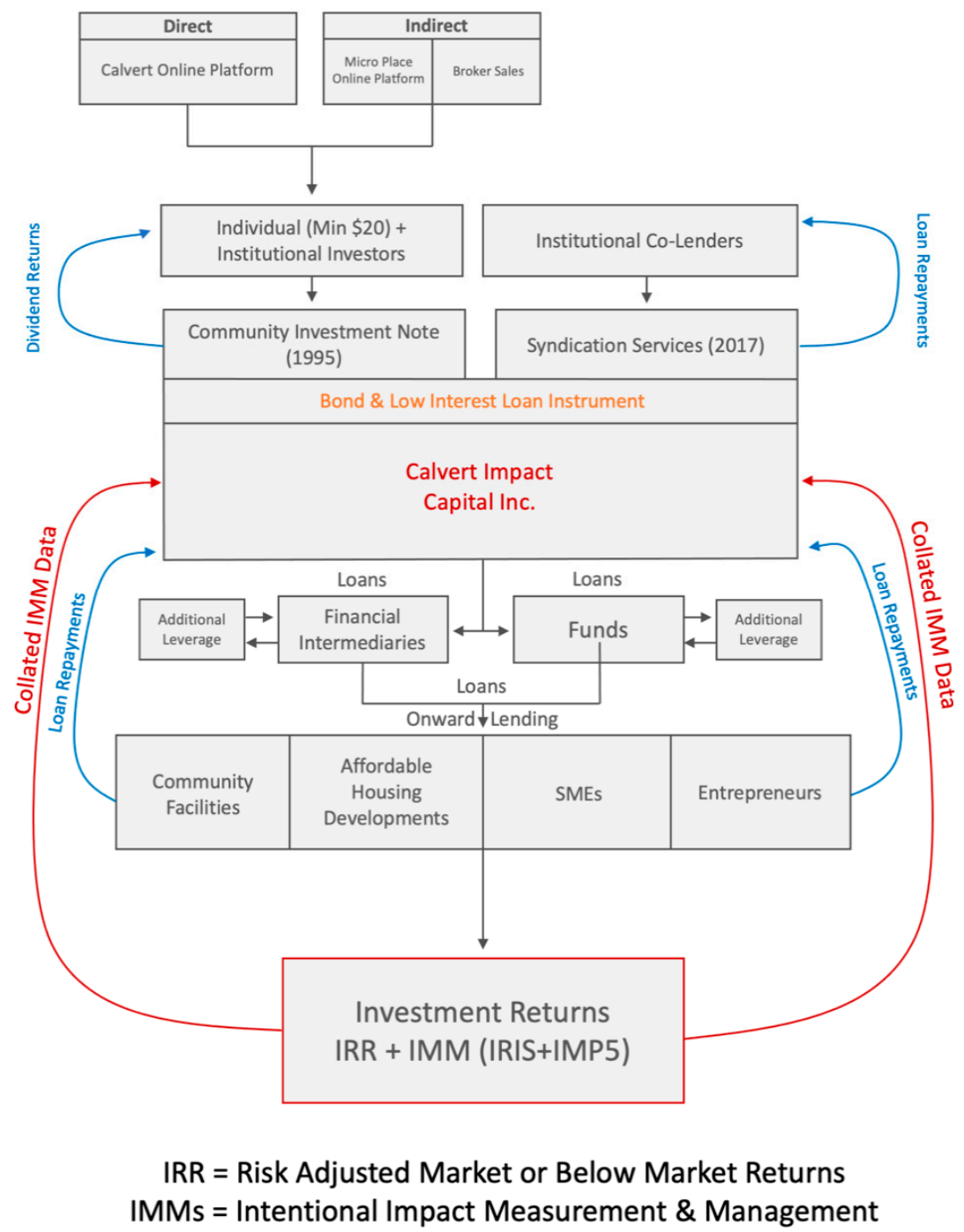

Figure 2. Calvert Impact Capital (CIC) Circular Impact Revolving Fund Structure. Source: Author based on Calvert Impact Capital Documentation [59].

\section{Concluding Observations}

This article maps the creation on an integrated panoptic investment leverage toolkit, incorporating umbrella categories of both financial and non-financial instruments, together with identified social enterprise capital investment leverage enablers. This mapping exercise highlights mutually beneficial stakeholder relationships that encourage circular investment in cultural heritage adaptive reuse activities.

The umbrella categories offer a structured basis for more informed trans-national knowledge sharing and comparison of financial and non-financial leverage strategies, by creating a framework for the efficient clustering of previously successful individual, blended or pooled capital leverage instruments. The CLIC project has started this process by identifying a range of 'patterns of use' investment leverage case studies to identify a range of tools within each umbrella category. This strategy begins the process of building a benchmark to assess future market innovations and potentially enable transparent decision making regarding an institutional ecological approach to future investment leverage instrument choice and design.

Given the complex nature and range of cultural heritage activities, involving diversified stakeholders and a diverse range of hybrid financial and non-financial instruments, 
there is inevitable overlap within the categorization process. For example, inclusion of a category for 'Heritage Regulation and Real Estate Instruments' is necessary in the context of adaptive reuse of tangible built heritage assets, although overlaps may arise as heritage real estate instruments typically engage a range of blended financial (grant, tax, debt, equity tools) and non-financial (risk mitigation, impact metric and capacity building tools) instruments.

The growth of potential social enterprise investment collaborators, now working alongside the public sector, has created new opportunities to channel capital towards achieving efficient sustainable cultural heritage regeneration outcomes. It follows that prospective aggregation of financial resources and leverage possibilities also expands with increased collaboration possibilities.

Challenges arise in multilateral stakeholder funding engagement where there may be discrepancies in the alignment of impact focused investment goals, such as required risk adjusted market or below market financial return, by the different investor partner motivations. To address this issue a number of human and institutional capacity building networking, mobilising and mentoring platforms have emerged to assist stakeholder matchmaking and alignment of investment agendas.

A critical investment bottleneck still exists in creating sustainable investment leverage for small scale local community cultural heritage activities, particularly in disadvantaged urban and depopulated rural locations. Work still remains to cultivate 'connective networking infrastructure' to foster tactical relationships between 'grassroot' cultural heritage initiatives and cash-rich capital investment markets. The use of risk mitigation and capacity building instruments, aligned with the development of evolving digital network pathfinding tools, is vital to bridging the connective infrastructure gap to open up micro investment leverage opportunities for local communities.

Varying socio-cultural, environmental, economic and political contexts throughout Europe highlight the importance of hybrid financial instruments and fund structures remaining flexible in order to engage with differing state aid traditions and governance approaches. The level of investment required in cultural landscape management projects depends on numerous country specific factors such as the extent of obsolescence and degradation of existing built heritage assets, geographic location, demographic trends, urban configurations, municipal revenue generation, heritage protection regulatory policy, the level of a country's economic development and the ability to mobilize financial resources.

Capital market invest strategies rely heavily on market sentiment in addition to increasing reliance on intentional impact metrics. Cultural heritage adaptive reuse activities have the potential to engage circular investment strategies aimed at preserving social, cultural, environmental and economic values, while at the same time adapting obsolete built heritage for new, extended and/or shared uses. Intentional impact measurement and management (IMM) metrics are central to this process in order to justify sustainable investment streams. The development of hybrid financial solutions will not be sustainable unless they are designed and tailored to remain empathetic to people and ecosystems in parallel with vulnerable cultural heritage resources. Only then will cultural heritage capital investment strategies make the transition to circularity.

Funding: This research is funded by the European Union Horizon 2020 research and innovation programme under Grant Agreement No. 776758. Research Project CLIC: Circular models Leveraging Investments in Cultural heritage adaptive reuse.

Institutional Review Board Statement: Not applicable.

Informed Consent Statement: Not applicable.

Data Availability Statement: No new data was created or analysed in this study. Data sharing is not applicable to this article.

Acknowledgments: The author gratefully thanks Cathal Power, TU Dublin, for assisting in the design of infographics for Figures 1 and 2. 
Conflicts of Interest: The author declares no conflict of interest.

\section{References}

1. UN Habitat. World Cities Report: The Value of Sustainable Urbanisation. 2020. Available online: https://unhabitat.org/sites/ default/files/2020/11/world_cities_report_2020_abridged_version.pdf (accessed on 4 January 2021).

2. ECA. European Court of Auditors, EU Investments in Cultural Sites: A Topic That Deserves More Focus and Coordination, Special Report 08/2020. 2020. Available online: https://op.europa.eu/webpub/eca/special-reports/cultural-investments-08-2020/en/ (accessed on 29 December 2020).

3. EIB. Togetherness a New Heritage Deal for Europe, Written by Hermann Parzinger, 15th Essay in Big Ideas Series of European Investment Bank. 2020. Available online: https://www.eib.org/en/essays/new-heritage-deal-for-europe (accessed on 5 February 2021).

4. Von der Leyen. State of the Union Address by President von der Leyen at the European Parliament Plenary, 16th September 2020, Brussels (Speech/20/1655). 2020. Available online: https:/ / ec.europa.eu/commission/presscorner/detail/en/AC_20_1916 (accessed on 10 December 2020).

5. CAE; ECF; EHA. Cultural Deal for Europe jointly Developed by Culture Action Europe (CAE), European Cultural Foundation (ECF), and Europe Nostra \& European Heritage Alliance (EHA). 2020. Available online: http://cultureactioneurope.org/news/aculture-deal-for-europe (accessed on 3 January 2021).

6. EU. The Human Centred City: Recommendations for Research and Innovation Actions, Independent Expert Report. 2020 Available online: https:/ / op.europa.eu/en/publication-detail/-/publication/5b85a079-2255-11ea-af81-01aa75ed71a1/languageen/format-PDF/source-search (accessed on 11 February 2021).

7. EP. Resolution of 20 January 2021 (2019/2194(INI)) P9_TA-PROV(2021)0008, Initiated by MEP Dace Melbarde (ECR Latvia). 2021. Available online: https:/ / www.europarl.europa.eu/doceo/document/A-9-2020-0210_EN.html (accessed on 6 February 2021).

8. Quaedvlieg-Mihailovic. Speech by Sneska Quaedvlieg-Mihailovic. 2021. Available online: https://www.europanostra.org/epplenary-adopts-ambitious-report-on-the-legacy-of-the-european-year-of-cultural-heritage/ (accessed on 13 February 2021).

9. Potts, A. European Cultural Heritage Green Paper, Europa Nostra, The Hague \& Brussels. 2021. Available online: https: / /issuu.com/europanostra/docs/20210322-european_cultural_heritage_green_paper_fu (accessed on 5 April 2021).

10. EC. A New Circular Economy Action Plan for a Cleaner and More Competitive Europe, Brussels, 11.1.2020, COM (2020) 98 final. 2020. Available online: https:/ / eur-lex.europa.eu/legal-content/EN/TXT/?uri=CELEX\%3A52020DC0098 (accessed on 10 February 2021).

11. ARUP, BAM \& CE100. Circular Business Models for the Built Environment, ARUP, BAM, CE100, Supported by Ellen MacArthur Foundation. 2016. Available online: https:/ / www.ellenmacarthurfoundation.org/ce100/the-programme/enabling-collaboration (accessed on 14 September 2020).

12. ARUP. The Circular Economy in the Built Environment. 2016. Available online: https://www.arup.com/perspectives/ publications / research/section/ circular-economy-in-the-built-environment (accessed on 14 September 2020).

13. ARUP \& EMF. From Principles to Practice: Realising the Value of Circular Economy in Real Estate. 2020. Available online: https: //www.arup.com/perspectives/publications/research/section/realising-the-value-of-circular-economy-in-real-estate (accessed on 27 January 2021).

14. EC. A Renovation Wave for Europe Greening our Buildings, Creating Jobs, Improving Lives, Building Brussels, 14.10.2020, COM(2020) 662. 2020. Available online: https://eur-lex.europa.eu/legal-content/EN/TXT/?uri=CELEX\%3A52020DC0662 (accessed on 9 November 2020).

15. EU. Renovation Wave: The European Green Deal. 2020. Available online: https://ec.europa.eu/commission/presscorner/detail/ en/FS_20_1844 (accessed on 2 January 2021). [CrossRef]

16. CLIC Project Deliverables. Available online: https:/ / www.clicproject.eu/deliverables/ (accessed on 20 April 2021).

17. Kobalt, C. Optimising the Use of Cultural Heritage. In Economic Perspectives on Cultural Heritage; Hutter, M., Rizzo, I., Eds.; MacMillan: London, UK, 1997.

18. Vecco, M. A Definition of Cultural Heritage: From the Tangible to the Intangible. J. Cult. Herit. 2010, 11, 321-324. [CrossRef]

19. Hutter, M.; Rizzo, I. (Eds.) Economic Perspectives on Cultural Heritage; MacMillan: London, UK, 1997.

20. Throsby, D. Seven Questions in the Economics of Cultural Heritage. In Economic Perspectives on Cultural Heritage; Hutter, M., Rizzo, I., Eds.; MacMillan Press Ltd.: London, UK, 1997; pp. 13-30.

21. Throsby, D. Heritage Economics: A Conceptual Framework. In The Economics of Uniqueness, Investing in Historic City Cores and Cultural Heritage Assets for Sustainable Development; Urban Development Series; Liccoardi, G., Amirtahmasebi, R., Eds.; The World Bank: Washington, DC, USA, 2012; Available online: https:/ / openknowledge.worldbank.org/handle/10986/12286 (accessed on 2 November 2020).

22. Foster, G.J. Circular Economy Strategies for Adaptive Reuse of Cultural Heritage Buildings to Reduce Environmental Impacts, Resources Conservation Recycling 152 104507, Elsevier. 2020. Available online: https:/ / doi.org/10.1016/j.resconree.2019.104507 (accessed on 9 February 2021).

23. Ellen MacArthur Foundation Definition of Circular Economy. Available online: https://www.ellenmacarthurfoundation.org/ explore/the-circular-economy-in-detail (accessed on 4 February 2021). 
24. Girard, L.F. Implementing the circular economy: The role of cultural heritage as the entry point. Which evaluation approaches? BDC Boll. Del Cent. Calza Bini 2019, 9, 245-277. Available online: https://doi.org/10.6092/2284-4732/7269 (accessed on 10 December 2020).

25. Pickerill, T.; Armitage, L. The Management of Built Heritage, A Comparative Review of Policies \& Practice in Western Europe, North America \& Australia, Pacific Rim Real Estate Society Conference, Sydney. 2009. Available online: https://arrow.tudublin ie/beschreccon/36/ (accessed on 20 January 2021).

26. Girard, L.F.; Gravagnuolo, A. Circular Economy and Cultural Heritage /Landscape Regeneration. Circular business, financing and governance models for a competitive Europe, Circular City and Cultural heritage Interplay. BDC Boll. Del Cent. Calza Bini 2018, 17, 35-52. Available online: https:/ / doi.org/10.6092/2284-4732/5472 (accessed on 10 December 2020).

27. EC. The Just Transition Mechanism: Making sure no one is left behind. 2020. Available online: https://ec.europa.eu/commission/ presscorner/detail/en/fs_20_39 (accessed on 11 March 2021). [CrossRef]

28. Gianoncelli, A.; Boiardi, P. Financing for Social Impact-The Key Role of Tailored Financing and Hybrid Finance. Available online: https:/ / evpa.eu.com/uploads/publications/EVPA_Financing_for_Social_Impact_2017_online.pdf (accessed on 3 January 2021).

29. Volkmann, C.; Tokarski, K.; Ernst, K. Financing Social Entrepreneurship in Volkmann Tokarski and Ernst. In Social Entrepreneurship and Social Business; Springer Gabler: Wiesbaden, Germany, 2012.

30. Salamon, L.M. (Ed.) New Frontiers of Philanthropy; Oxford University Press: Oxford, UK, 2014; ISBN 978-0-19-935754-3.

31. Leigland, J. Public Private Partnership in Developing Countries: The emerging evidenced based critique. World Bank Res. Obs. 2018, 33, 103-134. [CrossRef]

32. O'Shea, C.; Palcic, D.; Reeves, E. Using PPP to Procure Social Infrastructure: Lessons Learned from 20 years of experience in Ireland. Public Works Manag. Policy 2020. [CrossRef]

33. EPEC. Value for Money Assessment: Review of Approaches and Key Concepts, European PPP Expertise Centre with European Investment Bank. 2015. Available online: https://www.eib.org/en/publications/epec-value-for-money-assessment (accessed on 10 February 2021).

34. EPEC. Hurdles to PPP Investments: A Contribution to the Third Pillar of the Investment Plan for Europe, IMF Fiscal Affairs Department, European PPP Expertise Centre with European Investment Bank. 2016. Available online: https://www.eib.org/en/ publications / hurdles-to-ppp-investments (accessed on 12 February 2021).

35. IMF. Public Private Partnerships, IMF Fiscal Affairs Department. 2004. Available online: https://www.imf.org/external/np/ fad/2004/pifp/eng/031204.pdf (accessed on 2 February 2021).

36. OECD. Public Private Partnerships: In Pursuit of Risk Sharing and Value for Money. 2008. Available online: https://www.oecd. org/gov/budgeting/public-privatepartnershipsinpursuitofrisksharingandvalueformoney.htm (accessed on 10 February 2021).

37. World Bank Institute. Value for Money Analysis, Practices and Challenges, World Bank Institute (WBI). 2013. Available online: http:/ / documents1.worldbank.org/curated/en/724231468331050325/pdf/840800WP0Box380ey0Analysis00PUBLIC0 .pdf (accessed on 10 February 2021).

38. O'Shea, C.; Palcic, D.; Reeves, E. Comparing PPP with traditional procurement: The case for schools procurement in Ireland. Ann. Public Coop. Econ. 2019, 90, 245-267. [CrossRef]

39. OECD. Social Impact Investing_Building the Evidence Base. 2015. Available online: https:// read.oecd-ilibrary.org/finance-andinvestment/social-impact-investment_9789264233430-en\#page1 (accessed on 2 February 2021).

40. WEF/OECD. Blended Finance Vol.1 A Primer for Development Finance and Philanthropic Funders. 2015. Available online: http: //www3.weforum.org/docs/WEF_Blended_Finance_A_Primer_Development_Finance_Philanthropic_Funders.pdf (accessed on 5 February 2021).

41. EIB. Introducing Financial Instruments for the European Social Fund, Fi-Compass. 2016. Available online: https://www.ficompass.eu (accessed on 14 February 2021).

42. EIB. Stocktaking Study on Financial Instruments by Sector, Fi-Compass ERDF. 2020. Available online: www.fi-compass.eu (accessed on 14 February 2021).

43. OECD. Blended Finance Principles for Sustainable Development. 2020. Available online: http://www.oecd.org/ officialdocuments/publicdisplaydocumentpdf/?cote=DCD/DAC(2020)42/FINAL\&docLanguage=En (accessed on 6 February 2021).

44. ECA. European Court of Auditors, Rapid Case Review: Reporting on Sustainability: A Stocktake of EU Institutions and Agencies, June 2019. Available online: https://www.eca.europa.eu/Lists/ECADocuments/RCR_Reporting_on_sustainability/RCR_ Reporting_on_sustainability_EN.pdf (accessed on 4 February 2021).

45. MSCI. The MSCI Principles of Sustainable Investing, Morgan Stanley Capital International. 2019. Available online: https://www. msci.com/documents/10199/16912162/MSCI-ESG-House-View-FINAL.pdf/63bba1a1-aecf-ba80-aa49-7910748ed942 (accessed on 3 February 2021).

46. Kempeneer, S.; Peeters, M.; Compernolle, T. Bringing the User Back in the Building: Analalysis of ESG in Real Estate and a Behavioral Framework to Guide Future Research. Sustainability 2021, 13, 3239. [CrossRef]

47. ESMA. Letter to Commissioner in Charge of Financial Services, Financial Stability and Capital Markets Union of the European Commission, from European Securities and Markets Authority, ESMA 30-379-423 28 January 2021, Signed by Steven Maijoor. 2021. Available online: https:/ / www.esma.europa.eu/sites/default/files/library / esma30-379-423_esma_letter_to_ec_on_esg_ ratings.pdf (accessed on 10 February 2021). 
48. EC. Acton Plan: Financing Sustainable Growth, COM(2018) 097 Final, Brussels 8.3.2018. 2019. Available online: https://ec. europa.eu/transparency/regdoc/rep/1/2018/EN/COM-2018-97-F1-EN-MAIN-PART-1.PDF (accessed on 2 January 2021).

49. EU. Regulation 2020/852 on the Establishment of a Framework to Facilitate Sustainable Investment, and Amending Regulation (EU) 2019/2008. 18 June 2020. Available online: https:/ / eur-lex.europa.eu/legal-content/EN/TXT/?uri=celex:32020R0852 (accessed on 14 February 2021).

50. EU TEG. Taxonomy: Final Report of the Technical Expert Group on Sustainable Finance. 2020. Available online: https://knowledge4policy.ec.europa.eu/publication/sustainable-finance-teg-final-report-eu-taxonomy_en (accessed on 6 February 2021).

51. EU TEG. EU Technical Expert Group on Sustainable Finance, Statement of the EU TEG on Sustainable Finance. Five High Level Princi-ples for Recovery and Resilience. 2020. Available online: https:/ / ec.europa.eu/info/publications/sustainable-financetechnical-expert-group_en (accessed on 4 February 2021).

52. EIB. A Sustainable Way of Achieving EU Economic and Social Objectives: Financial Instruments, Fi-Compass. 2015. Available online: https://www.fi-compass.eu/sites/default/files/publications/ESIF_A_sustainable_way_of_achieving_EU_economic_ and_social_objectives_EN.pdf (accessed on 2 February 2021).

53. Linneman, P.; Kirsch, B. Real Estate Finance E Investments Risks and Opportunities, 5th ed.; Linneman Associates: Philadelphia, PA, USA, 2020; ISBN 978-1-7923-3191-6.

54. GIIN. Impact Investing Decision Making Insights on Financial Performance, Global Impact Investing Network. 2021. Available online: https: / thegiin.org/research/publication/impact-investing-decision-making-insights-on-financial-performance (accessed on 17 February 2021).

55. GIIN. The State of Impact Measurement and Practice, 2nd ed.; Global Impact Investing Network. 2020. Available online: https:/ / thegiin.org/research/publication/imm-survey-second-edition (accessed on 2 February 2021).

56. Gianoncelli, A.; Martínez, A.P. The Investing for Impact Toolkit; European Venture Philanthropy Association (EVPA). 2020. Available online: https:/ / evpa.eu.com/knowledge-centre/publications/investing-for-impact-toolkit (accessed on 1 February 2021).

57. GIIN. Annual Impact Survey 2020, 10th ed., Global Impact Investing Network. 2020. Available online: https://thegiin.org/ research/publication/impinv-survey-2020 (accessed on 2 February 2021).

58. Gianoncelli, A.; Boiardi, P. Impact Strategies-How Investors Drive Social Impact; European Venture Philanthropy Association (EVPA): Brussels, Belgium, 2018; ISBN 9789082494082. Available online: https:/ / evpa.eu.com/uploads/publications/EVPA_ Impact_Strategies_2018.pdf (accessed on 2 February 2021).

59. CIC. Calvert Impact Capital Impact Report 2020: Investing for a More Equitable World, USA. 2020. Available online: https: / / www.calvertimpactcapital.org/impact/2020-impact-report (accessed on 11 February 2021).

60. Calvert Impact Capital Portfolio Alignment with SDGs. Available online: www.calvertimpactcapital.org/portfolio/sdgs (accessed on 10 February 2021).

61. Calvert Impact Capital Portfolio List. Available online: www.calvertimpactcapital.org/portfolio/list (accessed on 10 February 2021). 